\title{
Influenza vaccine effectiveness in Spain 2013/14: subtype-specific early estimates using the cycEVA study
}

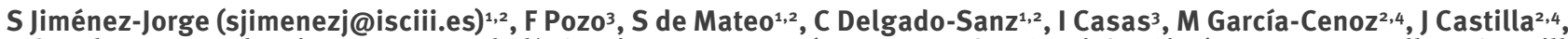
R Sancho $^{2,5}$, L Etxebarriarteun-Aranzabal ${ }^{6}$, C Quinones ${ }^{7}$, E Martínez $^{7}$, T Vega ${ }^{8}$, A Garcia $^{8}$, J Giménez ${ }^{9}$, J M Vanrell ${ }^{9}$, D Castrillejo ${ }^{10}$, A Larrauri ${ }^{1,2}$, on behalf of the Spanish Influenza Sentinel Surveillance System (SISS) ${ }^{11}$

1. National Centre of Epidemiology, Institute of Health Carlos III, Madrid, Spain

2. CIBER Epidemiología y Salud Pública (CIBERESP), Institute of Health Carlos III, Madrid, Spain

3. National Centre for Microbiology, National Influenza Reference Laboratory, WHO National Influenza Centre, Institute of Health Carlos III, Madrid, Spain

4. Instituto de Salud Pública de Navarra, Pamplona, Spain

5. Dirección de Salud Pública y Adicciones de Gipuzkoa, País Vasco, Spain

6. Subdirección de Salud Pública y Adicciones de Araba/Álava, País Vasco, Spain

7. Servicio de Epidemiología y Prevención Sanitaria, Dirección General de Salud Pública y Consumo de La Rioja, La Rioja, Spain

8. Dirección General de Salud Pública, Consejería de Sanidad de Castilla y León, Castilla y León, Spain

9. Servicio de Epidemiología, Dirección General de Salut Pública, Baleares, Spain

10. Servicio de Epidemiología, Dirección General de Sanidad y Consumo, Consejería de Bienestar Social y Sanidad, Ciudad Autónoma de Melilla, Melilla, Spain

11. The members are listed at the end of the article

Citation style for this article:

Jiménez-Jorge S, Pozo F, de Mateo S, Delgado-Sanz C, Casas I, García-Cenoz M, Castilla J, Sancho R, Etxebarriarteun-Aranzabal L, Quinones C, Martínez E, Vega T, Garcia A, Giménez J, Vanrell JM, Castrillejo D, Larrauri A, on behalf of the Spanish Influenza Sentinel Surveillance System (SISS). Influenza vaccine effectiveness in Spain 2013/14: subtype-specific early estimates using the cycEVA study. Euro Surveill. 2014;19(9):pii=20727. Available online: http://www.eurosurveillance.org/ ViewArticle.aspx?Articleld $=20727$

Article submitted on 14 February 2014 / published on 06 March 2014

Adjusted early estimates of the 2013/14 influenza vaccine effectiveness (VE) in Spain for all age groups was $35 \%(95 \% \mathrm{Cl}:-9$ to 62$), 33 \%(95 \% \mathrm{Cl}:-33$ to 67$)$ and $28 \%(95 \% \mathrm{Cl}:-33$ to 61$)$ against any influenza virus type, $\mathrm{A}\left(\mathrm{H}_{1} \mathrm{~N}_{1}\right)$ pdmo9 and $\mathrm{A}\left(\mathrm{H}_{3} \mathrm{~N}_{2}\right)$ viruses, respectively. For the population targeted for vaccination, the adjusted VE was $44 \%$ (95\% Cl: -11 to 72 ), $36 \%$ (95\% Cl: -64 to 75 ) and $42 \%$ (95\% Cl: -29 to 74 ), respectively. These preliminary results in Spain suggest a suboptimal protective effect of the vaccine against circulating influenza viruses.

\section{Early assessment of influenza vaccine} effectiveness in Spain at national level In the current influenza season, Spain has experienced a relatively early influenza epidemic compared with other European countries [1]. We present here nationwide early estimates of the effectiveness of the $2013 / 14$ seasonal trivalent influenza vaccine in Spain in preventing medically attended laboratory-confirmed influenza-like illness (ILI) infections, by virus type and subtype in all age groups and in the population targeted for vaccination, during the time when the influenza epidemic in Spain was increasing (9 December 2013 to 26 January 2014). Our early estimates suggest a suboptimal protective effect of the vaccine in preventing medically attended $A\left(\mathrm{H}_{1} \mathrm{~N}_{1}\right)$ pdmog and $A\left(\mathrm{H}_{3} \mathrm{~N}_{2}\right)$ laboratory-confirmed influenza.

\section{Background}

Since 2008, Spain has been providing interim influenza vaccine effectiveness (VE) results using the
cycEVA study - casos y controles para la Efectividad de la Vacuna Antigripal [cases and controls for monitoring influenza vaccine effectiveness], the Spanish component of the I-MOVE (Monitoring Vaccine Effectiveness in Europe) network [2,3]. The agreement between interim and final influenza VE estimates supports the use of interim assessments as a proxy for final VE results $[4,5]$.

In February 2013, the Vaccine Strain Selection Committee of the World Health Organization (WHO) formally received for the first time a compilation of preliminary influenza VE estimates for the 2012/13 season from Europe, Canada and the United States (US) [6]. Interim estimates 2013/14 and final 2013 estimates of influenza VE from countries in the northern and southern hemisphere, respectively, together with results of the characterisation of influenza viruses and vaccine serological studies, have contributed again this year to the decision of the Committee in February on the recommended composition of influenza vaccines for the forthcoming (2014/15) northern hemisphere influenza season [7]. Interim 2013/14 VE estimates have shown substantial protection against laboratory-confirmed $\mathrm{A}\left(\mathrm{H}_{1} \mathrm{~N}_{1}\right)$ pdmog illness in Canada and US [8,9] but suboptimal protection against this subtype in the Spanish Navarre region [10].

The results presented here at national level - the first at national level in Europe, in a scenario of multiple Spanish regions with probable differences in some epidemiological features or circulating viruses - might 


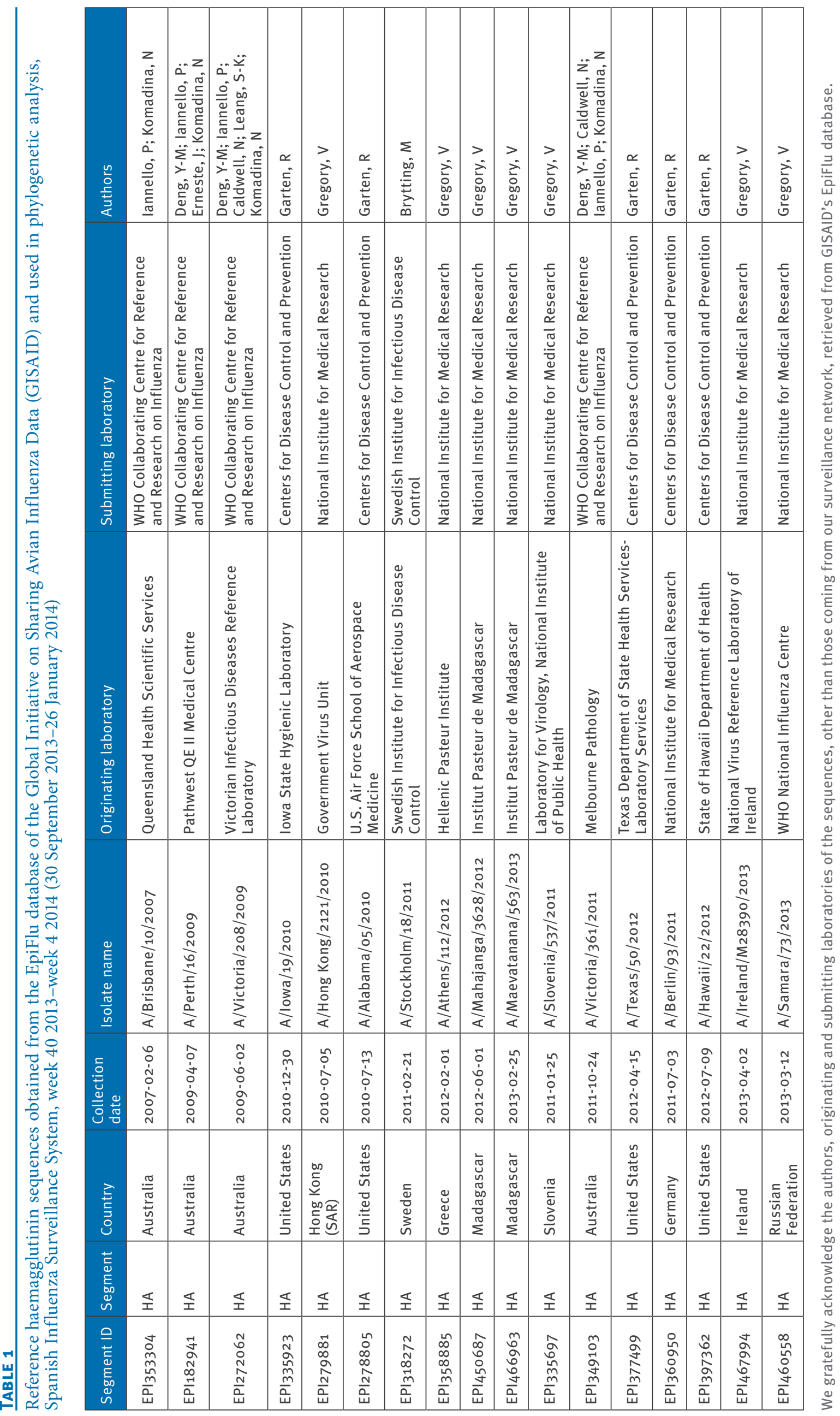


Recruited influenza cases $(\mathrm{n}=445)$ and test-negative controls $(\mathrm{n}=229)$ and influenza-like illness incidence in sentinel regions, cycEVA study, Spain, week 50 2013-week 42014 (9 December 2013-26 January 2014)

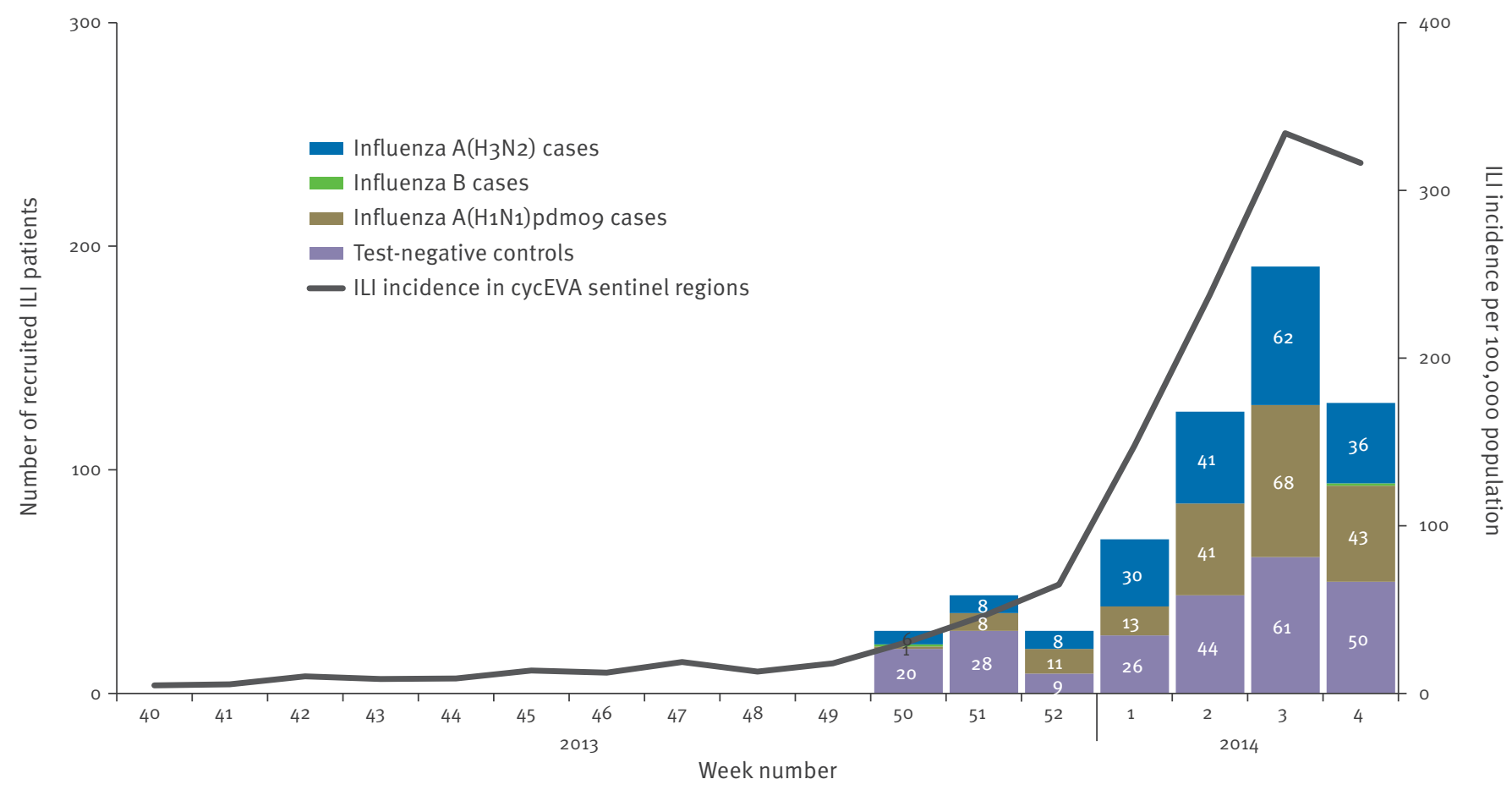

CycEVA: casos y controles para la Efectividad de la Vacuna Antigripal [cases and controls for monitoring influenza vaccine effectiveness]; ILI: influenza-like illness.

add substantial value to the previous estimates from Navarre regarding the suboptimal protective effect of the vaccine. By sharing these results with the scientific community, we are providing evidence that will help to fill the current gaps in knowledge of the relationship between antigenic match and the reported effectiveness of the vaccine.

\section{Estimating vaccine effectiveness and determining virus type}

In the $2013 / 14$ influenza season, six of the 17 regional networks belonging to the Spanish Influenza Sentinel Surveillance System participated in the cycEVA study. The methods used were similar to those carried out in previous seasons in the cycEVA study [11].

Influenza cases were ILI patients who tested positive for influenza virus using real-time reverse-transcription polymerase chain reaction or virus culture. Controls were ILI patients with swabs testing negative for any type of influenza virus.

The WHO National Influenza Centre in Madrid selected a subset of influenza isolates from the entire sentinel surveillance system for genetic characterisation by sequencing the amplified $\mathrm{HA}_{1}$ fragment of the viral haemagglutinin gene. Isolates were selected in order to be as representative as possible of viruses circulating in all Spanish regions. Thus they included viruses collected in every phase of the influenza season (beginning, epidemic peak and end of the season). They were also selected to include all ages, irrespective of the vaccination status of the patients. Phylogenetic analysis and molecular evolutionary analyses of the $\mathrm{HA}_{1}$ sequences was conducted using MEGA version 5 [12] in order to characterise the influenza A strains. Reference haemagglutinin nucleotide sequences were obtained from the Global Initiative on Sharing Avian Influenza Data (GISAID) [13] (Table 1).

We used logistic regression to calculate influenza VE from week 50 (starting 9 December) 2013 to week 4 (starting 26 January) 2014, including in the model potential confounding factors and restricting the analysis to those swabbed within seven days of symptom onset. In a sensitivity analysis, we calculated influenza VE in the population targeted for vaccination (individuals over six months-old with chronic conditions, people with risk factors (pregnancy, in women aged 15-44 years, or morbid obesity (body mass index $\geq 40 \mathrm{~kg} /$ $\mathrm{m}^{2}$ ), people aged over 59 years (over 64 years in some regions), healthcare workers and caregivers). 
Characteristics of laboratory-confirmed cases with influenza $\mathrm{A}(\mathrm{H} 1 \mathrm{~N} 1) \mathrm{pdm} 09$ or $\mathrm{A}(\mathrm{H} 3 \mathrm{~N} 2)$ viruses and test-negative controls, cycEVA study, Spain, week 50 2013-week 42014 (9 December 2013-26 January 2014) (n=601)

\begin{tabular}{|c|c|c|c|c|c|}
\hline \multirow[t]{2}{*}{ Variables } & $\begin{array}{l}\text { Test-negative controls, } \\
\qquad n=229^{a}\end{array}$ & $\begin{array}{c}\text { Influenza } A\left(\mathrm{H}_{1} \mathrm{~N}_{1}\right) \mathrm{pdmog} \\
\text { cases, } n=184^{\mathrm{a}}\end{array}$ & \multirow[t]{2}{*}{ P value ${ }^{b, c}$} & $\begin{array}{c}\text { Influenza } \\
\mathrm{A}\left(\mathrm{H}_{3} \mathrm{~N}_{2}\right) \text { cases } \\
n=188^{\mathrm{a}}\end{array}$ & \multirow[t]{2}{*}{$P$ value $e^{c, d}$} \\
\hline & $\begin{array}{l}\text { Number/total number } \\
(\%)^{\mathrm{e}}\end{array}$ & $\begin{array}{l}\text { Number/ } \\
\text { total number }(\%)^{\mathrm{e}}\end{array}$ & & $\begin{array}{l}\text { Number/ } \\
\text { total number (\%) }\end{array}$ & \\
\hline \multicolumn{6}{|l|}{ Age group in years } \\
\hline $0-4$ & $22 / 229(9.6)$ & $7 / 184(3.8)$ & \multirow{4}{*}{0.005} & $13 / 188(6.9)$ & \multirow{4}{*}{0.617} \\
\hline $5-14$ & $30 / 229(13.1)$ & $30 / 184(16.3)$ & & $20 / 188(10.6)$ & \\
\hline $15-64$ & $153 / 229(66.8)$ & $140 / 184(76.1)$ & & $135 / 188(71.8)$ & \\
\hline$\geq 65$ & $24 / 229(10.5)$ & $7 / 184(3.8)$ & & $20 / 188(10.6)$ & \\
\hline Median age in years (range) & $36(0-92)$ & $37(1-80)$ & $0.868^{f}$ & $37(0-89)$ & $0.778^{\mathrm{e}}$ \\
\hline Male & $121 / 229(52.8)$ & $102 / 184(55.4)$ & 0.599 & $94 / 188(50.0)$ & 0.564 \\
\hline Any chronic condition reported & $50 / 228(21.9)$ & $32 / 184(17 \cdot 4)$ & 0.251 & $47 / 187(25.1)$ & 0.443 \\
\hline Any risk factor reported ${ }^{g}$ & $6 / 211(2.8)$ & $5 / 184(2.7)$ & 0.947 & $5 / 165(3.0)$ & 0.915 \\
\hline $\begin{array}{l}\text { Any hospitalisation for chronic } \\
\text { conditions in previous year }\end{array}$ & $0 / 229(0)$ & $3 / 184(1.6)$ & 0.052 & $0 / 188(0)$ & 0.100 \\
\hline $\begin{array}{l}\text { Median number of visits to a GP } \\
\text { or pediatrician in previous year } \\
\text { per patient (range) }\end{array}$ & $3(0-44)$ & $3(0-36)$ & $0.450^{f}$ & $3(0-27)$ & $0.775^{\mathrm{f}}$ \\
\hline Smoker & $38 / 227(16.7)$ & $23 / 184(12.5)$ & 0.229 & $24 / 186(12.9)$ & 0.277 \\
\hline $\begin{array}{l}\text { Interval between symptom onset } \\
\text { and swabbing less than } 4 \text { days }\end{array}$ & $223 / 229(97.4)$ & $178 / 184(96.7)$ & 0.700 & $184 / 188(97.9)$ & 0.744 \\
\hline $\begin{array}{l}\text { Population targeted for } \\
\text { vaccination }\end{array}$ & $78 / 218(35.8)$ & $43 / 184(23.4)$ & 0.027 & $66 / 172(38.4)$ & 0.598 \\
\hline \multicolumn{6}{|l|}{ Vaccination status } \\
\hline \multicolumn{6}{|l|}{ All ages } \\
\hline $\begin{array}{l}\text { Received seasonal 2013/14 } \\
\text { vaccine }^{\text {h }}\end{array}$ & $38 / 229(16.6)$ & $21 / 184(11.4)$ & 0.085 & $30 / 188(16.0)$ & 0.681 \\
\hline $\begin{array}{l}\text { Received both seasonal } \\
2013 / 14 \text { and } 2012 / 13 \text { vaccines }\end{array}$ & $35 / 229(15 \cdot 3)$ & 20/184 (10.9) & 0.278 & 28/188 (14.9) & 0.623 \\
\hline \multicolumn{6}{|l|}{ Targeted for vaccination } \\
\hline $\begin{array}{l}\text { Received seasonal 2013/14 } \\
\text { vaccine }^{\text {h }}\end{array}$ & $28 / 78(35.9)$ & $12 / 43(27.9)$ & 0.371 & $17 / 66(25.8)$ & 0.191 \\
\hline $\begin{array}{l}\text { Received both seasonal } \\
2013 / 14 \text { and } 2012 / 13 \text { vaccines }\end{array}$ & $24 / 78(30.8)$ & $11 / 43(25.6)$ & 0.760 & $16 / 66(24.2)$ & 0.424 \\
\hline
\end{tabular}

GP: general practitioner; ILI: influenza-like illness.

a Cases and controls recruited during the specified time period and with an interval between ILI symptom onset and swabbing of less than eight days.

b $P$ value for $A\left(\mathrm{H}_{1} \mathrm{~N}_{1}\right)$ pdmog cases versus controls.

c Chi-squared test or Fisher's exact test.

d $P$ value for $A\left(\mathrm{H}_{3} \mathrm{~N}_{2}\right)$ cases versus controls.

e Unless otherwise indicated. The denominator changes for variables in which the information was missing for some patients.

f Non-parametric test of the median.

g Defined as pregnancy (in women aged 15-44 years) and/or morbid obesity (body mass index $\geq 40 \mathrm{~kg} / \mathrm{m}^{2}$ ).

h Vaccination at least 14 days before the onset of influenza like illness symptoms.

\section{Early national vaccine effectiveness estimates}

\section{Description of the 2013/14 influenza season in Spain}

The 2013/14 influenza season in Spain started in week 1 (30 December 2013-5 January 2014) and reached the epidemic peak in week 4 (20-26 January 2014) at both the national level and in the six regions participating in the cycEVA study [14]. It was a medium-intensity influenza season, clearly dominated by mixed circulation of influenza $A$ viruses: $61 \%(571 / 929) \mathrm{A}\left(\mathrm{H}_{1} \mathrm{~N}_{1}\right)$ pdmog and 39\% (358/929) $\mathrm{A}\left(\mathrm{H}_{3} \mathrm{~N}_{2}\right)$ influenza [14].

\section{Participants' characteristics}

Among the 217 participating sentinel physicians in the study, $167(77 \%)$ recruited at least one ILI patient. Of the $687 \mathrm{ILI}$ patients recruited, 202 (29\%) belonged to the population targeted for influenza vaccination. After excluding 15 patients swabbed more than seven days 
Crude and adjusted seasonal vaccine effectiveness estimates against laboratory-confirmed influenza by virus type/subtype, overall and among the target population for influenza vaccination, cycEVA study, Spain, week 502013 -week 42014

(9 December 2013-26 January 2014)

\begin{tabular}{|c|c|c|c|}
\hline Population included & All influenza viruses & Influenza $\mathrm{A}\left(\mathrm{H}_{1} \mathrm{~N}_{1}\right)$ pdmo9 & Influenza $\mathrm{A}\left(\mathrm{H}_{3} \mathrm{~N}_{2}\right)$ \\
\hline \multicolumn{4}{|l|}{ All patients } \\
\hline Number of patients for the analysis: cases + controls & 674 & 413 & 417 \\
\hline Number of cases/controls & $445 / 229$ & $184 / 229$ & $188 / 229$ \\
\hline Number of vaccinated cases/vaccinated controls & $53 / 38$ & $21 / 38$ & $30 / 38$ \\
\hline Crude VE \% (95\% Cl) & $32(-7$ to 56$)$ & $35(-15$ to 63$)$ & $5(-61$ to 43$)$ \\
\hline Adjusted VE $\%(95 \% \mathrm{Cl})$ & $35(-9$ to 62$)$ & $33(-33$ to 67$)$ & $28(-33$ to 61$)$ \\
\hline \multicolumn{4}{|l|}{ Population targeted for vaccination } \\
\hline Number of patients for the analysis: cases + controls & 299 & 121 & 144 \\
\hline Number of cases/controls & $121 / 78$ & $43 / 78$ & $66 / 78$ \\
\hline Number of vaccinated cases/vaccinated controls & $30 / 27$ & $12 / 27$ & $17 / 27$ \\
\hline Crude VE \% $(95 \% \mathrm{Cl})$ & $38(-16$ to 67$)$ & $27(-65$ to 98$)$ & $34(-35$ to 68$)$ \\
\hline Adjusted VE $\%$ (95\% Cl) & $44(-11$ to 72$)$ & $36(-64$ to 75$)$ & $42(-29$ to 74$)$ \\
\hline
\end{tabular}

$\mathrm{Cl}$ : confidence interval; VE: vaccine effectiveness.

a Adjusted for age (age groups adjusted for: $0-4,5-14,15-64$ and $\geq 65$ years), sex, severity, number of general practitioner visits, smoking history (had ever smoked), chronic conditions, pregnancy (in women aged $15-44$ years), morbid obesity (body mass index $\geq 40 \mathrm{~kg} / \mathrm{m}^{2}$ ) and week of swabbing.

after symptom onset, 674 ILI patients were included in the study, comprising 445 influenza cases - 188 with influenza $A\left(\mathrm{H}_{3} \mathrm{~N}_{2}\right)$ virus, $184 \mathrm{~A}\left(\mathrm{H}_{1} \mathrm{~N}_{1}\right)$ pdmo9, 71 influenza A not subtyped and two with influenza B virusand 229 test-negative controls (Figure 1).

The percentage of the population targeted for vaccination was higher in the controls $(35.8 \%, 78 / 218$,) than in the $\mathrm{A}\left(\mathrm{H}_{1} \mathrm{~N}_{1}\right)$ pdmog cases $(23.4 \%, 43 / 184)$ (Table 2). Vaccine coverage with the $2013 / 14$ influenza vaccine was not statistically different among controls and $\mathrm{A}\left(\mathrm{H}_{1} \mathrm{~N}_{1}\right)$ pdmog or $\mathrm{A}\left(\mathrm{H}_{3} \mathrm{~N}_{2}\right)$ cases, in all age groups and among the population targeted for vaccination. The majority of cases (96.7-97.9\%, 178/184-184/188) and controls $(97.4 \%, 223 / 229)$ were swabbed less than four days after symptom onset.

Of the 89 people vaccinated, there were 54 vaccine failures: 30 were positive for influenza $A\left(\mathrm{H}_{3} \mathrm{~N}_{2}\right)$ virus, 21 for influenza $A\left(\mathrm{H}_{1} \mathrm{~N}_{1}\right) p d m o g$ virus and three with an unknown influenza virus. Of the 54 vaccine failures, 30 were cases belonging to the target population for vaccination.

\section{Vaccine effectiveness estimates}

The adjusted influenza VE for all age groups was $35 \%$ (95\% Cl: -9 to 62 ), $33 \%$ (95\% Cl: -33 to 67 ) and $28 \%$ (95\% Cl: -33 to 61 ) against any influenza virus type, $\mathrm{A}\left(\mathrm{H}_{1} \mathrm{~N}_{1}\right)$ pdmog and $\mathrm{A}\left(\mathrm{H}_{3} \mathrm{~N}_{2}\right)$ viruses, respectively (Table 3).

Among the population targeted for vaccination, the adjusted influenza VE against any influenza virus type, $\mathrm{A}\left(\mathrm{H}_{1} \mathrm{~N}_{1}\right)$ pdmog and $\mathrm{A}\left(\mathrm{H}_{3} \mathrm{~N}_{2}\right)$ viruses was $44 \%(95 \% \mathrm{Cl}$ :
-11 to 72 ), $36 \%$ (95\% Cl: -64 to 75$)$ and $42 \%(95 \% \mathrm{Cl}$ : -29 to 74 ), respectively (Table 3 ).

Genetic analysis of selected isolates

Sequence analysis of the amplified HA1 genome fragments showed that all 93 influenza $A\left(\mathrm{H}_{1} \mathrm{~N}_{1}\right)$ pdmo9 viruses studied clustered into the group $6 \mathrm{~B}$ [15] represented by $A /$ Norway/2417/2013 and defined by D97N, K163Q, S185T, S203T, A256T and K283E amino acid mutations compared with the vaccine virus $A$ / California/07/2009.

Regarding influenza $\mathrm{A}\left(\mathrm{H}_{3} \mathrm{~N}_{2}\right)$ virus, all 61 viruses studied clustered into the group $3 \mathrm{C}$ [15] which includes the $\mathrm{A} /$ Texas/50/2012 vaccine virus strain, but harboured some amino acid changes that make it possible to differentiate them into two subsets (named 3 C.2 and 3C.3) (representative isolates are shown in Figure 2, including viruses collected in past seasons for a better understand the genetic drift of influenza $A$ viruses). Six of the 61 viruses clustered within subgroup 3 C.2 represented by $A /$ Ireland/M28390/2013, defined by the $\mathrm{HA}_{1}$ amino acid substitution N128T. The remaining 55/61 viruses (90\%) clustered within the subgroup $3 \mathrm{C} .3$ represented by $\mathrm{A} / \mathrm{Samara} / 73 / 2013$ and defined by $\mathrm{N}_{128} \mathrm{~A}$ and R142G amino acid substitutions. Interestingly, we could differentiate 23 viruses within the 3 C.3 subgroup with an additional L157S change, most of them (20 of 23) harbouring a second N122D mutation. Another subset of six viruses harbouring the K160R amino acid substitution could be identified within the ${ }_{3} C .3$ subgroup. Changes in influenza $\mathrm{A}\left(\mathrm{H}_{3} \mathrm{~N}_{2}\right)$ viruses were referred to the $A / T e x a s / 50 / 2012$ vaccine virus strain. 


\section{FIGURE 2}

Phylogenetic tree showing genetic differences in HA1 fragment of the haemagglutinin of influenza A(H3N2) circulating viruses, Spanish Influenza Surveillance System, Spain, week 40 2013-week 42014 (30 September 2013-26 January 2014)

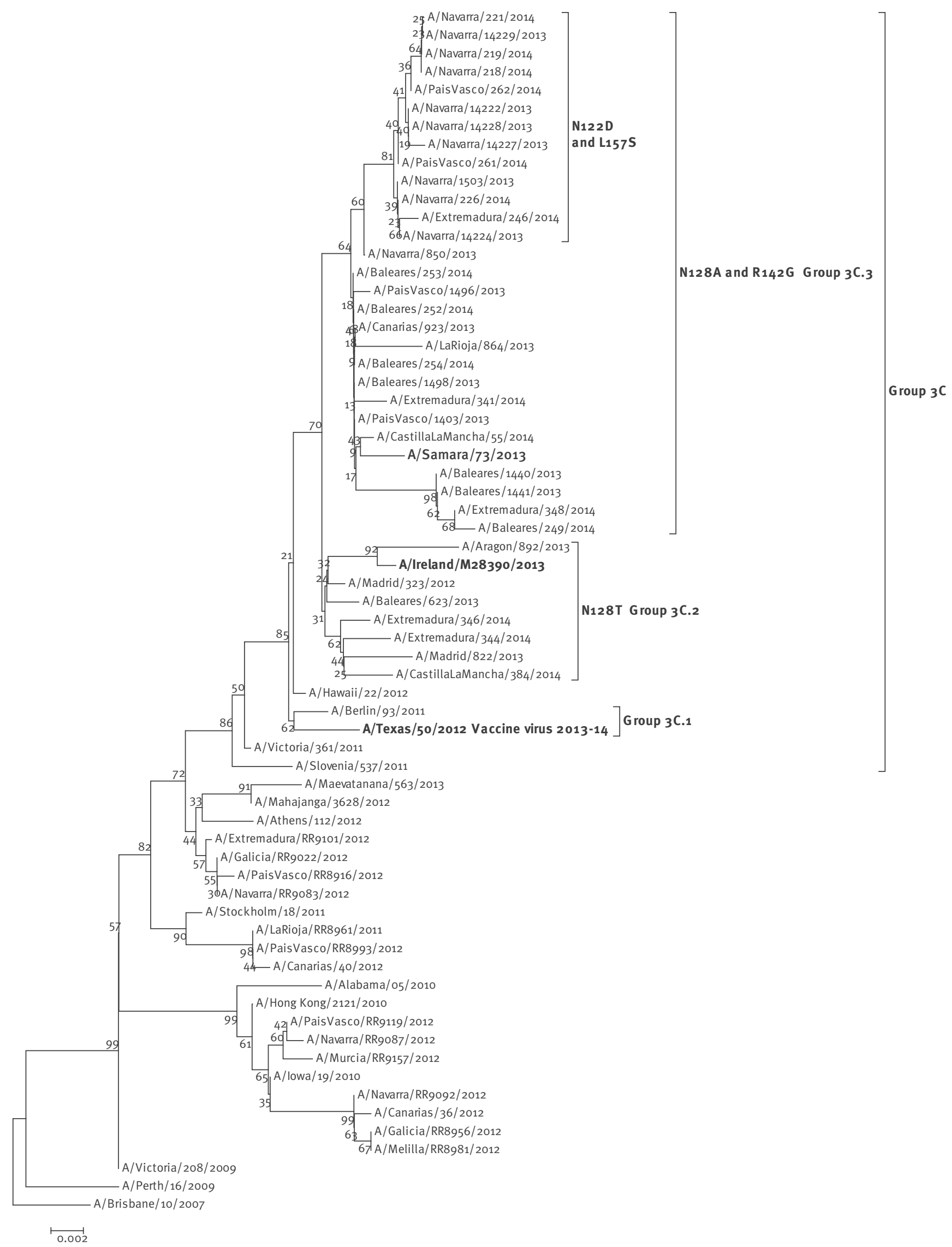

Phylogenetic relationships were inferred using the MEGA5 programme applying the neighbor-joining method and the Kimura 2-parameter model [12]. Representative isolates are shown, including viruses collected in past seasons to illustrate genetic drift. Viruses in bold are representative of groups 3 C.1, 3 C.2 and 3 C.3, according to the European Centre for Disease Prevention and Control's Influenza virus characterisation [15]. 


\section{Discussion}

Our interim point estimate in preventing $\mathrm{A}\left(\mathrm{H}_{1} \mathrm{~N}_{1}\right)$ pdmog infections was $33 \%$ in a $2013 / 14$ season with circulating $\mathrm{A}\left(\mathrm{H}_{1} \mathrm{~N}_{1}\right)$ pdmog strains antigenically similar and genetically well conserved at the European level, as of week 4/2014 $[15,16]$. Suboptimal protective effects against well-conserved $\mathrm{A}\left(\mathrm{H}_{1} \mathrm{~N}_{1}\right)$ pdmo9 virus were previously described in Europe during the 2011/12 season by the I-MOVE network [17]. In Spain, during the 2010/11 season, early VE estimates against well-matched $\mathrm{A}\left(\mathrm{H}_{1} \mathrm{~N}_{1}\right)$ pdmog virus were also found to be lower than $50 \%(49 \% ; 95 \% \mathrm{Cl}: 3$ to 73$)$ [2], which were highly consistent with the final estimates, $46 \%$ (95\% Cl: o to 72 ) [18]. Estimates recently published by Canada and the US for the $2013 / 14$ season $[8,9]$ against $A\left(\mathrm{H}_{1} \mathrm{~N}_{1}\right)$ pdmog were higher than our results. $A$ higher protective effect of the vaccine against $A\left(\mathrm{H}_{1} \mathrm{~N}_{1}\right)$ pdmog in North America compared with Spain could be due to different characteristics of the circulating $\mathrm{A}\left(\mathrm{H}_{1} \mathrm{~N}_{1}\right)$ pdmo9 viruses: most of the viruses analysed were shown to be antigenically similar to the vaccine strain in Canada and the US. In Spain, antigenic tests for $\mathrm{A}\left(\mathrm{H}_{1} \mathrm{~N}_{1}\right)$ pdmog virus are unfortunately not yet available. In addition, in light of the positive effect of previous influenza vaccination described in Canada [19] and Spain [18], a higher proportion of the population previously vaccinated with the 2009 monovalent pandemic vaccine in Canada (about 40\%) [8] compared with that in Spain $(\leqslant 10 \%)[18,20]$ could partly explain the higher VE estimates observed in Canada. The use of different types of influenza vaccine could also contribute to the differences between the results of both studies. However, our results were in line (VE below $50 \%$ ) with those recently published by the Navarre region [10], a Spanish region that also participates in the cycEVA study and I-MOVE network. In the Navarre study, patients recruited in primary healthcare and in hospitals were included, giving similarly low influenza VE estimates in both settings. These observations were in accordance with the evolution of the influenza epidemic in Spain this season: a considerably higher number of severe hospitalised laboratory-confirmed cases were seen than in the two previous seasons. Of these cases, $40 \%$ had received the seasonal influenza vaccine [13]. The reasons behind these highly variable estimates of VE are still unclear.

Subtype-specific estimates of VE for influenza $A\left(\mathrm{H}_{3} \mathrm{~N}_{2}\right)$ were also in the lower range of VE points described in previous seasons (range: $25-60 \%$ [11,21-23]), with adjusted estimates of $28 \%$ and $42 \%$ for all age groups and population targeted for vaccination, respectively. Reduced protection from influenza $\mathrm{A}\left(\mathrm{H}_{3}\right)$ infection has been described in previous seasons worldwide, including in Spain and the rest of Europe during the 2011/12 season, when $\mathrm{A}\left(\mathrm{H}_{3}\right)$ last circulated as the predominant virus, but was poorly matched to the vaccine $[11,23]$. The importance of the amino acid changes we describe in the circulating $\mathrm{A}\left(\mathrm{H}_{3} \mathrm{~N}_{2}\right)$ virus in Spain will be studied at the end of the season once the haemagglutination inhibition assays have been carried out. However, it is important to highlight that the L157S and N122D mutations identified are located in the $\mathrm{HA}_{1}$ antigenic sites $B$ and $A$, respectively, of $A\left(\mathrm{H}_{3} \mathrm{~N}_{2}\right)$ viruses: this could indicate a suboptimal protective effect of the current vaccine against $A\left(\mathrm{H}_{3} \mathrm{~N}_{2}\right)$ virus in Spain.

For the 2014/15 northern hemisphere influenza season, WHO has recommended the inclusion of the same strains included in the current seasonal influenza vaccine [24]. Final estimates in Spain with a larger sample size will allow us to confirm the extent of the protective value of the 2013/14 influenza vaccine in Spain and could give an indication of what could be expected in other countries in the northern hemisphere

Although VE estimates are subject to change over time, some studies have demonstrated agreement between interim and final influenza VE estimates, with early estimates within five to seven percentage points of final estimates $[5,22]$. Using the cycEVA study, the early $[2,3]$ and final estimates $[11,18]$ of the influenza VE in the 2010/11 and 2011/12 seasons in Spain have been similar.

The main limitation of our study was the sample size, which makes estimates for virus subtypes imprecise; therefore, final estimates should be obtained at the end of the influenza season.

Early estimates of influenza VE can help to guide health authorities in influenza prevention and provide useful information for the WHO strain selection process. Future influenza VE studies worldwide are necessary to gain more knowledge about which virus amino acid changes could be influencing the protective effect of the current influenza vaccines. Although our results indicate the protection against $\mathrm{A}\left(\mathrm{H}_{1} \mathrm{~N}_{1}\right)$ pdmog and $A\left(H_{3} \mathrm{~N}_{2}\right)$ viruses was suboptimal, the VE was higher among those at risk of severe influenza complications, underlying the importance of annual influenza vaccination. The suboptimal protective effect of the vaccine should also lead to a clear public health message underlying the importance of early antiviral treatment for patients at high risk of influenza complications, and the adoption of non-pharmacological preventive measures to avoid influenza infection.

\section{Members of the Spanish Influenza Sentinel Surveillance System (SISS)}

Physicians of the influenza sentinel surveillance networks of: Andalucía, Aragón, Asturias, Baleares, Canarias, Cantabria, Castilla La Mancha, Castilla y León, Cataluña, Comunitat Valenciana, Extremadura, Madrid, Navarra, País Vasco, La Rioja, Ceuta and Melilla.

Epidemiologist members of the SISS belonging to: Servicio de Epidemiología y Salud Laboral , Consejería de Salud, Junta de Andalucía.; Servicio de Vigilancia en Salud Pública, Dirección General de Salud Pública, Aragón; Dirección General de Salud Pública y Planificación, Consejería de Salud y Servicios Sanitarios, Asturias; Servicio de Epidemiología, Dirección General de Salut Pública, Baleares; Sección de Epidemiología, Consejería de Sanidad, Trabajo y Servicios Sociales de Canarias.; Sección de Epidemiología, 
Consejería de Sanidad, Trabajo y Servicios Sociales de Cantabria; Servicio de Epidemiología, Consejería de Sanidad de Castilla la Mancha; Dirección General de Salud Pública e Investigación, Desarrollo e Innovación, Consejería de Sanidad de Castilla y León; Servicio de Vigilancia Epidemiológica, DGSP, Departament de Salut, Generalitat Catalunya; Subdirección General de Epidemiologia y Vigilancia de la Salud, Conselleria de Sanitat, Comunitat Valenciana; Dirección General de Salud Pública, Servicio Extremeño de Salud, Junta de Extremadura.; Dirección Xeral de Innovación e Xestión da Saúde Pública de Galicia.; Dirección General de Atención Primaria de la Comunidad de Madrid; Servicio de Epidemiología. Consejería de Sanidad de la Región de Murcia; Instituto de Salud Pública de Navarra; Servicio de Vigilancia Epidemiológica, Consejería de Sanidad del País Vasco, Dirección de Salud Pública de Gipuzkoa; Servicio de Epidemiología y Prevención Sanitaria. Dirección General de Salud Pública y Consumo de La Rioja.; Sección de Vigilancia Epidemiológica, Consejería de Sanidad y Bienestar Social de Ceuta; Servicio de Epidemiología. Dirección General de Sanidad y Consumo, Consejería de Bienestar Social y Sanidad. Ciudad Autónoma de Melilla.

Virologist members of the SISS belonging to the following laboratories: Centro Nacional de Gripe-Madrid, Centro Nacional de Microbiología, ISCIII, Majadahonda; Centro Nacional de Gripe-Valladolid, Facultad de Medicina de Valladolid; Centro Nacional de Gripe- Barcelona, Hospital Clinic de Barcelona; Servicio de Microbiología, Hospital Virgen de las Nieves de Granada, Andalucía; Servicio de Microbiología, Hospital Miguel Servet de Zaragoza, Aragón; Servicio de Microbiología, Hospital Universitario Central de Asturias de Oviedo, Asturias; Servicio de Microbiología, Hospital Son Espases de Palma de Mallorca. Baleares; Servicio de Microbiología, Hospital Dr. Negrín de Las Palmas de Gran Canaria, Canarias; Servicio de Microbiología, Hospital Universitario Marqués de Valdecilla de Santander; GeneralLab S.A., Comunitat Valenciana; Servicio de Microbiología, Hospital San Pedro de Alcántara de Cáceres, Extremadura; Servicio de Microbiología, Hospital Universitario Ramón y Cajal, Madrid, Servicio de Microbiología, Clínica Universitaria de Navarra, Pamplona, Navarra; Servicio de Microbiología del Complejo Hospitalario de Navarra; Servicio de Microbiología, Hospital Donostia, País Vasco; Servicio de Microbiología, Hospital San Pedro, de Logroño, La Rioja; Servicio de Microbiología, Hospital de INGESA de Ceuta; Servicio de Microbiología del Complejo Hospitalario de Vigo, Galicia; Servicio de Microbiología del Complejo Hospitalario de Ourense, Galicia; Servicio de Microbiología, Hospital Virgen de la Arrixaca de Murcia.

\section{Acknowledgements}

We are grateful to sentinel GPs, paediatricians and virologists participating in the cycEVA study, as well as to all professionals participating in the Spanish Influenza Surveillance System. We thank Marta Valenciano from EpiConcept for her fruitful comments.

We gratefully acknowledge the authors, originating and submitting laboratories of the sequences from GISAID's EpiFlu database on which this research is based (Table 1 ).

\section{Financial support}

This work was supported from the Influenza $A\left(\mathrm{H}_{1} \mathrm{~N}_{1}\right)$ pdmog Programme of the Carlos III Institute of Health (GRog/0017

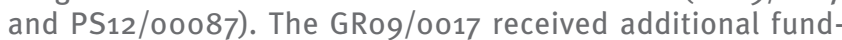
ing from the World Health Organization Regional Office for Europe (WHO/Europe)/United States CDC (Centers for Disease Control and Prevention) and Epiconcept.
Conflict of interest

None declared.

\section{Authors' contributions}

Silvia Jiménez-Jorge and Amparo Larrauri designed the study. Silvia Jiménez-Jorge wrote the first draft of the manuscript and undertook the statistical analysis. Silvia JiménezJorge, Salvador de Mateo and Amparo Larrauri participated in data analysis, writing and interpretation of the results. Francisco Pozo and Inmaculada Casas were responsible for the virus characterisation and contributed with the interpretation of the virological data. All authors participated in the interpretation of the data, contributed to the revision of the draft manuscript and approved the final version.

\section{References}

1. European Centre for Disease Prevention and Control (ECDC). Weekly influenza surveillance overview. 31 January 2014. Main surveillance developments in week 4/2013 (20-26 January 2014). Stockholm: ECDC; 2014. Available from: http:// ecdc.europa.eu/en/publications/Publications/influenzasurveillance-overview-31-jan-2014.pdf

2. Savulescu C, Jiménez-Jorge S, de Mateo S, Ledesma J, Pozo F, Casas I, et al. Effectiveness of the $2010 / 11$ seasonal trivalent influenza vaccine in Spain: preliminary results of a casecontrol study. Euro Surveill. 2011;16(11):pii=19820.

3. Jimenez-Jorge S, de Mateo S, Pozo F, Casas I, Garcia CM, Castilla J, et al. Early estimates of the effectiveness of the 2011/12 influenza vaccine in the population targeted for vaccination in Spain, 25 December 2011 to 19 February 2012. Euro Surveill. 2012;17(12):pii: 20129.

4. Belongia EA, Kieke BA, Donahue JG, Coleman LA, Irving SA, Meece JK, et al. Influenza vaccine effectiveness in Wisconsin during the 2007-08 season: comparison of interim and final results. Vaccine. 2011;29(38):6558-63. http://dx.doi. org/10.1016/j.vaccine.2011.07.002

5. Sullivan SG, Kelly H. Late season interim estimates of influenza vaccine effectiveness reliably predict end of season estimates in Victoria, Australia, 2007 to 2012. Euro Surveill. 2013;18(41): pii=20605. http://dx.doi.org/10.2807/1560-7917. ES2013.18.41.20605

6. European Centre for Disease Control and Prevention (ECDC). WHO Recommendation on influenza virus vaccines for the Northern Hemisphere 2013-2014 season. Stockholm: ECDC; 15 March 2013. Available from: http://www.ecdc.europa.eu/ en/activities/sciadvice/ layouts/forms/Review DispForm. aspx? ID =737\& List=a3216f4c-fo40-4f51-9f77-a96046 dbfd72

7. World Health Organization (WHO). Recommended composition of influenza virus vaccines for use in the northern hemisphere 2014-15 influenza season and development of candidate vaccine viruses for pandemic preparedness. Geneva: WHO; 2014. Questions and answers. Available from: http://www. who.int/influenza/vaccines/virus/recommendations/201402_ qanda_recommendation.pdf

8. Skowronski DM, Chambers C, Sabaiduc S, De Serres G, Dickinson JA, Winter AL, et al. Interim estimates of 2013/14 vaccine effectiveness against influenza $A\left(\mathrm{H}_{1} \mathrm{~N}_{1}\right)$ pdmo9 from Canada's sentinel surveillance network, January 2014. Euro Surveill. 2014;19(5):pii=20690. http://dx.doi. org/10.2807/1560-7917.ES2014.19.5.20690

9. Flannery B, Thaker SN, Clippard J, Monto AS, Ohmit SE, Zimmerman RK, et al. Interim estimates of 2013-14 seasonal influenza vaccine effectiveness - United States, February 2014. MMWR Morb Mortal Wkly Rep. 2014;63(7):137-42.

10. Castilla J, Martinez-Baz I, Navascues A, Fernandez-Alonso M, Reina G, Guevara M, et al. Vaccine effectiveness in preventing laboratory-confirmed influenza in Navarre, Spain: 2013/14 midseason analysis. Euro Surveill. 2014;19(6):pii=20700. http:// dx.doi.org/10.2807/1560-7917.ES2014.19.6.20700

11. Jiménez-Jorge S, de Mateo S, Delgado-Sanz C, Pozo F, Casas I, Garcia-Cenoz M, et al. Effectiveness of influenza vaccine against laboratory-confirmed influenza, in the late 2011-2012 season in Spain, among population targeted for vaccination. BMC Infect Dis. 2013;13(1):441. http://dx.doi. org/10.1186/1471-2334-13-441

12. Tamura K, Peterson D, Peterson N, Stecher G, Nei M, Kumar S. MEGA5: molecular evolutionary genetics analysis using 
maximum likelihood, evolutionary distance, and maximum parsimony methods. Mol Biol Evol. 2011;28(10):2731-9. http:// dx.doi.org/10.1093/molbev/msr121

13. The GISAID Initiative. GISAID. Available from: http://www. gisaid.com/

14. Instituto de Salud Carlos III. Informes anuales y semanales de Vigilancia de la Gripe en Espa-a. Sistema de Vigilancia de la Gripe en Espa-a. [Annual and weekly national influenza reports. Spanish Influenza Surveillance System]. Madrid: Centro Nacional de Epidemiología Instituto de Salud Carlos III; 2012. [Accessed 15 January 2014]. Spanish. Available from: http://www.isciii.es/cne-gripe-infsemanal

15. European Centre for Disease Prevention and Control (ECDC). Influenza virus characterisation. Summary Europe December 2013. Stockholm: ECDC; 2014. p. 1. Available from: http:// www.ecdc.europa.eu/en/publications/Publications/influenzavirus-characterisation-dec-2013.pdf

16. Instituto de Salud Carlos III. Informe semanal de Vigilancia de la gripe en Espa-a. Semana 05/2014 (27 de enero - 2 de febrero 2014). № 379. Comienza la fase de descenso de la onda epidémica 2013/14 en Espa-a, una vez sobrepasado el pico máximo de incidencia de gripe. Sistema de Vigilancia de la Gripe en Espa-a. [Influenza activity is decreasing in Spain after reaching the $2013 / 14$ influenza epidemic peak]. Madrid: Instituto de Salud Carlos III; 2014. Spanish. Available from: http://vgripe.isciii.es/gripe/documentos/20132014/boletines/ grno52014.pdf

17. Kissling E, Valenciano M. Early estimates of seasonal influenza vaccine effectiveness in Europe, 2010/11: I-MOVE, a multicentre case-control study. Euro Surveill. 2011;16(11):pii=19818.

18. Jiménez-Jorge S, Savulescu C, Pozo F, de Mateo S, Casas I, Ledesma J, et al. Effectiveness of the 2010-11 seasonal trivalent influenza vaccine in Spain: cycEVA study. Vaccine. 2012;30(24):3595-602. http://dx.doi.org/10.1016/j. vaccine.2012.03.048

19. Skowronski DM, Janjua NZ, Sabaiduc S, De Serres G, Winter AL, Gubbay JB, et al. Influenza A/subtype and B/lineage effectiveness estimates for the 2011-12 trivalent vaccine: cross-season and cross-lineage protection with unchanged vaccine. J Infect Dis. 2014; Jan 19. [Epub ahead of print]. http:// dx.doi.org/10.1093/infdis/jiu048

20. Savulescu C, Jiménez-Jorge S, De Mateo S, Pozo F, Casas I, Perez-Bre-a P, et al. Using surveillance data to estimate pandemic vaccine effectiveness against laboratory confirmed influenza $\mathrm{A}\left(\mathrm{H}_{1} \mathrm{~N}_{1}\right) 2009$ infection: two case control studies, Spain, season 2009-2010. BMC Public Health. 2011;11:899. http://dx.doi.org/10.1186/1471-2458-11-899

21. Fielding JE, Grant KA, Papadakis G, Kelly HA. Estimation of type- and subtype-specific influenza vaccine effectiveness in Victoria, Australia using a test negative case control method, 2007-2008. BMC Infect Dis. 2011;11:170. http://dx.doi. org/10.1186/1471-2334-11-170

22. Belongia EA, Kieke BA, Donahue JG, Greenlee RT, Balish A, Foust $A$, et al. Effectiveness of inactivated influenza vaccines varied substantially with antigenic match from the 2004-2005 season to the 2006-2007 season. J Infect Dis. 2009;199(2):15967. http://dx.doi.org/10.1086/595861

23. Kissling E, Valenciano M, Larrauri A, Oroszi B, Cohen JM, Nunes $B$, et al. Low and decreasing vaccine effectiveness against influenza $A\left(\mathrm{H}_{3}\right)$ in 2011/12 among vaccination target groups in Europe: results from the I-MOVE multicentre casecontrol study. Euro Surveill. 2013;18(5): pii=20390.

24. World Health Organization (WHO). Recommended composition of influenza virus vaccines for use in the 2014-2015 northern hemisphere influenza season. Geneva: WHO; 20 February 2014. Available from: http://www.who.int/influenza/vaccines/ virus/recommendations/2014_15_north/en/ 